\title{
Transgenic Potato (Solanumtuberosum) Expressing Two Antifungal Thionin Genes Confer Resistance To Fusarium Spp.
}

\author{
'I.A. Hammad ${ }^{1}$, A.B. Abdel-Razik², E.R. Soliman ${ }^{1}$, E. Tawfik ${ }^{1}$ \\ ${ }^{I}$ Botany and Microbiology Department, Faculty of Science, Helwan University, Egypt \\ ${ }^{2}$ Genetic Department, Faculty of Agriculture, Ain Shams University, Egypt \\ Corresponding Author: E. Tawfik
}

\begin{abstract}
Two thionin genes were isolated from Arabidopsis thaliana (AT1G12660 and AT1G12663). The resulted thionin protein has antifungal activity against potato pathogenic fungi like Fusariumsolani and Fusariumoxysporum. These two thionin genes were respectively inserted into pEGAD vector. After that transformed into Agrobacterium tumifaceins GV3101::pMP90 in order to be transformed into the two potato cultivars (lady and spunta) using nodal cutting technique of tissue culture. Expressions of thionin transgenes in the transgenic plants were confirmed by RT-PCR. There were two assays were applied to test the role of thionins (in the transgenic potatoes) in resistance to the pathogenic fungi: effect of spore suspension on potato organs and the inhibitory effect of thionin proteins on spore germination.As the transgenic potato plant possesses active defense systems and can protect themselves from pathogenic invasion by secretion of a variety of small antifungal proteins such as thionins. The resulted transgenic potato cultivars were tested for fungal infection in comparing to control by using spore suspension on leaf and micro-tuber. The results showed that transgenic potato cultivars were highly resistant to the symptoms comparing to control.The other bioassay was studying the effect of the expressed thionin protein in the transgenic potato against the spore germination of both F. solani and F. oxysporum. There was obvious decrease in the number of the germinated spores comparing to control.
\end{abstract}

Keywords:Solanumtuberosum, Arabidopsis thaliana,Agrobacterium Transformation,Fusariumsolani, Fusariumoxysporum, Thionin genes.

Date of Submission: 07-07-2017

Date of acceptance: 20-07-2017

\section{Introduction}

Solanumtuberosumbelongs to the family Solanaceae, is a popular vegetable in the worldand it is economically and socially important. It considered being the fourth most important food crop (after wheat, maize and rice). It is cultivated in temperate and subtropical regions across the world[1].

In Egypt, potato has animportant value among all vegetable crops, whereabout $20 \%$ of total area devoted for vegetable productionis cultivated with potato. Potato is the second most important vegetable crop after tomato. Potato is economicallyimportant to Egypt and any disturbance in its productionaffects severely its local and more importantly exportimpact.Because potato is one of the main crops among Egypt's agricultural exports, it is important to understand the relevant patterns and determinants of international trade in order to promote Egyptian agricultural exports. There are two main problems encounter production and exportation of potato in Egypt: infection with pathogenic diseases and using of chemical fungicides and pesticides. Firstly, during their seasonal plantationspotato plants are subjected to numerouspathogens and insect pests which cause considerableloss in Egyptian quantitative and qualitative potato yield.Thus, a key barrier to the improvement ofpotato in Egypt is the reduction in yield and tuber qualitycaused mainly by potato pests and pathogens [2,3 and 4].Secondly, theuse of pesticides and fungicides is costly as well as environmentally undesirable. Therefore, there is a great demand to develop novel strategies providing durable resistance, over a broad geographic area. Such strategies will be particularly important in cases where the source of resistance is not available. The most significant advancement in the area of varietal development for disease resistance is the use of the techniques of genetic engineering to develop transgenic plant resistant to many diseases [5,6,7,8 and 9].

Fungi are considered serious pathogens for many plants and can cause severe economic damage. Early detection of these pathogens is very important and might be critical for their control [10].Fusarium species are common in most soils where potatoes are grown and can survive as resistant spores free in the soil for very long periods of time. Fusariumsolanias it is the most common pathogen causing dry rot disease of potato. There are two main opportunities in the potato crop cycle for Fusarium species to infect potato tubers in the spring and the fall[11]. Where [12] described Fusariumoxysporum growth as it is favored by dry soil conditions and the optimum soil temperature for infection is $15^{\circ} \mathrm{C}$. Fusariumoxysporum causes Fusarium wilt which is a common 
vascular wilt fungal disease.Thioninsare family of the PR proteins with low-molecular-weight (5kDa) cysteinerich proteins, they had anti-microbial activity and toxic to plant pathogens in vitro (has antifungal properties). There are many kinds of thionins, most of which mainly accumulate in seeds of higher plants. But some thionins exist in stems, roots, or leaves in tissue specific manner. $\mathrm{N}$ - and C-terminal amino acid sequences of these thionins are highly conservative but their nucleotide sequences differentiate to each other[13, 14 and 15]. The mechanism of thionins inhibition to the pathogenic fungi was simply explained by [16] as follow: the antimicrobial properties of thionins are derived from their ability to induce pore formation on cell membranes of phytopathogens, resulting in release of potassium and calcium ions from the cell.

[17]mentioned that Agrobacterium-mediated transformation has become feasible. It is the most common method used for the genetic transformation of potato. Agrobacterium-mediated transformation offers several advantages over the other methods (particle bombardment, electroporation etc.), such as the possibility of transferring only one or few copies of DNA fragments carrying the genes of interest at higher efficiencies with lower cost and the transfer of very large DNAs fragments with minimal rearrangement.

In this study, we sought to introduce resistance potato plants to fungal pathogens by expressing antifungal thionin genes (Thio60 and Thio63). These two genes were transformed into the potato tissues by Agrobacterium-mediated gene transfer. We confirm the thionin gene transfer into the transgenic potato lines, and then tested the resistance of transgenic plants against the fungal pathogen Fusariumsolani and Fusariumoxysporum.

\section{Plant material:-}

\section{Materials And Methods}

Arabidopsis thaliana plant is agenetic model of thionin genes. It was used to isolate the thionin genes. Two cultivars ofSolanumtuberosum (potato) used as a transgenic model (lady and spunta). They were brought from Egyptian-Canadian Company (Egypt) and regenerated on MS media[18].

\section{Methods:-}

\subsection{Isolation of thionin genes from Arabidopsis thaliana:-}

The total genomic DNA of Arabidopsis thaliana was extracted using Edward's protocol described by [19]. For PCR reaction 50ng of template DNA was used for each $25 \mu 1$ reaction. Each reaction mixture contained $12.5 \mu \mathrm{l}$ of $2 \mathrm{X}$ master mix (Biolene), $0.25 \mu \mathrm{ltaq}$ polymerase (Biolene), $1 \mu \mathrm{l}$ of each forward and reverse primer (50nmole/base) and complete up to $25 \mu \mathrm{l}$ by sterile d.dH2O. The thionin primers were designed usingsnap gene ${ }^{\circledR}$ (2.3.3) software and there sequences were as follow: Thio60F: 5, GCTGAATTCATGGAGGACAAAAGA 3'，Thio60R: 5'GCTAAGCTTTCATAGACTAAAATCAAT 3'; where Thio63F: 5'GCTGAATTCATGTTGGTGGCAG $3^{\prime}$ and Thio63R: 5'GCTAAGCTTAGTTTTTCTTGGTAC 3'. PCR reaction for each gene was performed for 40 cycles as follow: $1 \mathrm{~min}$ at $95^{\circ} \mathrm{c}, 1 \mathrm{~min}$ at $64^{\circ} \mathrm{c}$ and $1 \mathrm{~min}$ at $72^{\circ} \mathrm{c}$. The two thionin genes to be determined were AT1G12660 (Thio-60) and AT1G12663 (Thio-63) genes and they are found on the chromosome one of Arabidopsis thaliana. PCR products for the isolated two thionin genes were run on $0.8 \%(\mathrm{w} / \mathrm{v})$ agarose gel. The amplified PCR products werepurified using GeneJETTM PCR Purification Kit (Thermo K0701).

\subsection{Bacterial strain and plasmid:-}

The cultures of E. coli (CD3-389) containingpEGADkindly provided from Agricultural center for genetic engineering and biotechnology (ACGEB) were grown for $24 \mathrm{~h}$ at $37^{\circ} \mathrm{c}$ on LB agar plates with the appropriate antibiotic for plasmid $(50 \mu \mathrm{g} / \mathrm{ml}$ kanamycin). Then make LB broth media at $200 \mathrm{rpm}$ in order to isolate the vector (pEGAD) using alkaline lysis method following the protocol of [20].

\subsection{Digestion, Cloning and bacterial transformation:-}

Both the two thionin genes and the vector (pEGAD) were digested with the same restriction enzymes (EcoRI and HindIII) from New England, Biolabs ${ }^{\circledR}$ Inc, according to the manufacture protocol. The ligation process was performed between the pEGAD plasmid and both inserts (Thio-60 and Thio-63 genes) respectively at conditions $37^{\circ} \mathrm{c}$ for $2 \mathrm{hr}[21]$. So the ligation product is ready for proceeding bacterial transformation.pEGAD vector carrying both Thio-60 and Thio-63 genes respectively were transformed into chemically competent $E$. coli cells. [21] mentioned the protocol of E. coli transformation as follow: $100 \mu l$ of competent cells were allowed to thaw on ice. $5 \mu$ of each plasmid DNA was added and incubated on ice for 30 minutes. Samples were subjected to $42^{\circ} \mathrm{C}$ for 1 minute and they were immediately transferred onto ice and left for 3 minutes. After heat shock $900 \mu \mathrm{SOC}$ medium was added onto bacterial culture. The samples were incubated at $37^{\circ} \mathrm{C}$ for $50-60$ minutes with shaking at $200 \mathrm{rpm}$. $100 \mu \mathrm{l}$ of each culture was spread onto wormed LB plate with $50 \mu \mathrm{g} / \mathrm{ml}$ kanamycin and were grown at $37^{\circ} \mathrm{C}$ overnight. After that, isolate the propagated plasmid with gene of interest in order to confirm the transformation into DH5 $\alpha$ by plasmid PCR. After that,transform the vector with thionin genes into Agrobacterium. 


\subsection{Plasmid PCR:-}

The vector (pEGAD) containing each of thionin genes were isolated from DH5 CD3-389 and a PCR reaction was established to confirm the cloning of the thionin genes inside the plasmid in the right direction $\left(5^{\prime}\right.$ 3) using the primers specific to the vector(pEGAD) as follow: Forward: 5' ACCTGCCAACCAAAGCGAGAAC $3^{\prime}$ and reverse: 5' TCAGGGTTATTGTCTCATGAGCG 3'. PCR reaction for plasmid PCR was performed for 40 cycles as follow: $1 \mathrm{~min}$ at $95^{\circ} \mathrm{c}, 1 \mathrm{~min}$ at $68^{\circ} \mathrm{c}$ and $1 \mathrm{~min}$ at $72^{\circ} \mathrm{c}$.

\subsection{Agrobacterium transformation:-}

Agrobacterium tumefaciens strain GV3101::pMP90 (pTiC58), kindly provided by ACGEB (Faculty of Agriculture, Ain-Shams University). The culture was allowed to grow in LB broth with containing $50 \mu \mathrm{g} / \mathrm{ml}$ gentamycin $100 \mu \mathrm{g} / \mathrm{ml}$ rifampicin at $28^{\circ} \mathrm{c}$ for $48 \mathrm{~h}$ with shaking at 250rpm.Chemically competent Agrobacteriumwas prepared according to [22]. Then transform the prepared plasmid (pEGAD with Thio-60 and Thio-63 respectively)with gene as follow: $50 \mathrm{ng}$ of plasmid DNA was mixed with a $100 \mu \mathrm{l}$ aliquot of competent Agrobacterium tumefaciens cells and held on ice for 15-30 min then freeze in liquid nitrogen for $5 \mathrm{~min}$. Then cells were transferred to $37^{\circ} \mathrm{C}$ water bath and incubated for $5 \mathrm{~min}$. $1 \mathrm{ml}$ of $\mathrm{LB}$ medium was added to the cells. The cells were mixed and incubated for $2-3 \mathrm{~h}$ at $28^{\circ} \mathrm{C}$ with shaking. Then $100 \mu \mathrm{l}$ of the cell suspension were spread onto selective LB plates (containing $50 \mu \mathrm{g} / \mathrm{ml}$ Kanamycin, $100 \mu \mathrm{g} / \mathrm{ml}$ Rifampicin and $50 \mu \mathrm{g} / \mathrm{ml}$ Gentamicin) and incubated at $28^{\circ} \mathrm{C}$ for two days [22].

\subsubsection{Transformationof Agrobacterium into plant tissue:-}

Nodal explants of $0.5-2.0 \mathrm{~cm}$ long were cut from the three-week old Solanumtuberosum cultivars plantlets. The explants were immersed in $50 \mathrm{ml}$ of Agrobacterium tumefaciens broth culture for 5 minutes. To remove extra bacteria, the explants were blotted on sterile filter paper and transferred on to a Petri plates (covered with filter paper) with hormone free MS medium and kept at $25 \pm 1^{\circ} \mathrm{C}$.The explants were not exposed to antibiotic at this stage[23 and 24]. Six replicate were performed and each plate contained ten nodal segments for selection.

\subsubsection{Selection and regeneration}

After co-cultivation for 72 hours the healthy explants were removed and washed with sterile $\mathrm{dH}_{2} \mathrm{O}$ then transferred on to $3 / 4 \mathrm{MS}$ medium containing $(2 \mathrm{mg} / \mathrm{l} \mathrm{BA}$ and $1 \mathrm{mg} / \mathrm{l} \mathrm{kin})$ and $50 \mu \mathrm{g} / \mathrm{l} \mathrm{kanamycin} \mathrm{then} \mathrm{incubated} \mathrm{at}$ $25 \pm 1^{\circ} \mathrm{C}$ for 4 weeks to regenerate plants. The produced transgenic potato cultivars were transferred into rooting MS media containing ( $1 \mathrm{ml} / 1 \mathrm{NAA}, 1 \mathrm{ml} / \mathrm{lBA}$ and $1 \mathrm{ml} / \mathrm{lin})$ and incubated at $25^{\circ} \mathrm{c}$ under light conditions (16h light and $8 \mathrm{~h}$ dark for 4 weeks[23 and 24].

\subsection{Molecular analysis of transgenic plants:-}

There were two confirmation assays were performed to confirm the transformation of the two thionin genesinto potato plants: PCR and RT-PCR

\subsubsection{PCR analysis}

A polymerase chain reaction (PCR) was employed to screen transformants for successful integration of thionin genes within the potato genome. Genomic DNAs from kanamycin-resistant and control potato plants 45 weeks old were extracted using a modified cetyltrimethylammonium bromide (CTAB) method according to [25]. PCR was performed using genomic DNA as a target and primers as follow: forward 60, 5'ATGGAGGACAAAAGAGTG3'; reverse 60, 5'TCATAGACTAAAATCAATAGC3'; forward 63, 5'ATGTTGGTGGCAGTAATGAT3'; and reverse 63, 5'CTAGTTTTTCTTGGTACACTT3'. These primers were designed by the software Oligo 7. PCR amplification reactions consistedof an initial denaturation at $95^{\circ} \mathrm{C}$ for $3 \mathrm{~min}$ followedby 40 cycles of denaturation at $95{ }^{\circ} \mathrm{C}$ for $1 \mathrm{~min}$, annealing at $54^{\circ} \mathrm{C}$ for $1 \mathrm{~min}$, extension at 72 ${ }^{\circ} \mathrm{C}$ for $1 \mathrm{~min}$ and a post- extension at $72{ }^{\circ} \mathrm{C}$ for $10 \mathrm{~min}$. Theresulting PCR products were analyzedon $1.2 \%$ agarose gel.

\subsubsection{Real time-PCR for the transgenic plant:-}

This reaction was performed in three steps: RNA extraction, cDNA synthesis and real time-PCR reaction. RNA was isolated from the transgenic line of both potato cultivars after four weeks cultivation in MS jars by using protocol of [26].cDNA was generated from total RNA using usingSuperScript $®$ III One-Step RTPCR System with Platinum ${ }^{\circledR}$ Taq DNA Polymerase (Thermo scientific).Real-Time PCR reactions were carried out to quantify selected gene transcripts using PikoReal Real-Time (Thermo scientific)and SYBER-green as fluorescent dye, according to the manufacturer's instructions. The amplified PCR products were fractionated through 1\% agarose gel. These transcripts were compared to actin control gene (Act7) expressed in Arabidopsis thaliana plant. A melting curve was recorded at the end of every run to exclude primers generating non-specific PCR products. 


\subsection{Fungal-resistance assay of transgenic plants:-}

\subsubsection{Spore suspension infecting different organs in potato}

In this experiment, spore suspension was prepared by immersing fungal discs in $5 \mathrm{ml}$ of sterile distilled water to release the spores. The spores were collected with a sterile Pasteur pipette, and their concentration was adjusted to $2 \times 10^{5}$ spores $/ \mathrm{ml}$ using sterile water. This assay was applied for two parts of potato cultivars (detached leaves and micro-tubers).Detached leaves from mature transgenic and non-transgenic potato cultivars, grown in vitro for 4-5 weeks which placed in a Petri dish with wet filter paper, wounded in the middle on both sides of the midrib, and inoculated with the spore suspension $(20 \mu \mathrm{l}$ each). Micro-tubers from mature transgenic and nontransgenicpotato plants, grown in vitro for about 8 weeks, were placed in a Petri dish with wet filter paper and inoculated with the spore suspension $(20 \mu \mathrm{l}$ each).After inoculation, these different organs were incubated at

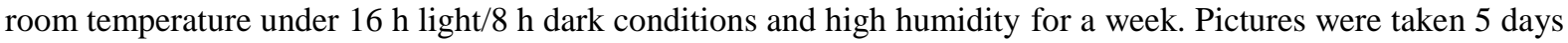
after inoculation (this protocol was according to [27] with some modifications).

\subsection{Protein extraction Bioassay}

Antifungal activity of the product thionin proteins resulted in the transgenic potato was tested against the different potato pathogenic fungi spores. The protein extraction was applied following the method of [28]. Then the following bioassay was applied:-

\subsubsection{Inhibitory effect of protein extracts on spore germination}

The antifungal effect of crude protein extract on germination of the different Fusariumspecies used was tested by spore germination method according to [29] with some modifications. Spore suspension of the pathogens was prepared aseptically from 7 days old pure culture. $100 \mu \mathrm{l}$ of spore suspension and $100 \mu \mathrm{L}$ of crude protein extracts were taken on separate sterile eppendorf tube. One tube was maintained as control without adding any extract. All treatments were maintained in triplicates. And the tubes were incubated at $25 \pm 2{ }^{\circ} \mathrm{C}$ for 24 h. After the incubation period, observations were made under microscope to calculate the percentage inhibition (using 100x magnification power under JENLAB microscope).

\section{Results}

In this study, Agrobacterium-mediated transformation was employed to transform potato with two different thionin genes (AT1G12660 and AT1G12663). Two commercial potato cultivars (lady and spunta) were used in this study. The transgenic plants exhibited enhanced resistance to Fusariumsolani and Fusariumoxysporum infection.

\section{Restriction digestion of thionin genes and vector:-}

Both the two thionin genes (AT1G12660 and AT1G12663) and the vector pEGAD were digested with EcoRI and HindIII. And the results were analyzed on agarose gel electrophoresis as illustrated in figure (1).

\section{Plasmid PCR}

The plasmids containing both thionin genes were isolated and a PCR reaction was established to confirm the cloning of the thionin genes into the plasmid. This is illustrated in figure (2) which indicated that four lanes shown right insertion while three were not for gene 60; and the same for gene 63; and both in comparing to control gene in lane one. After that both two thionin genes were purified from gel for sequencing.
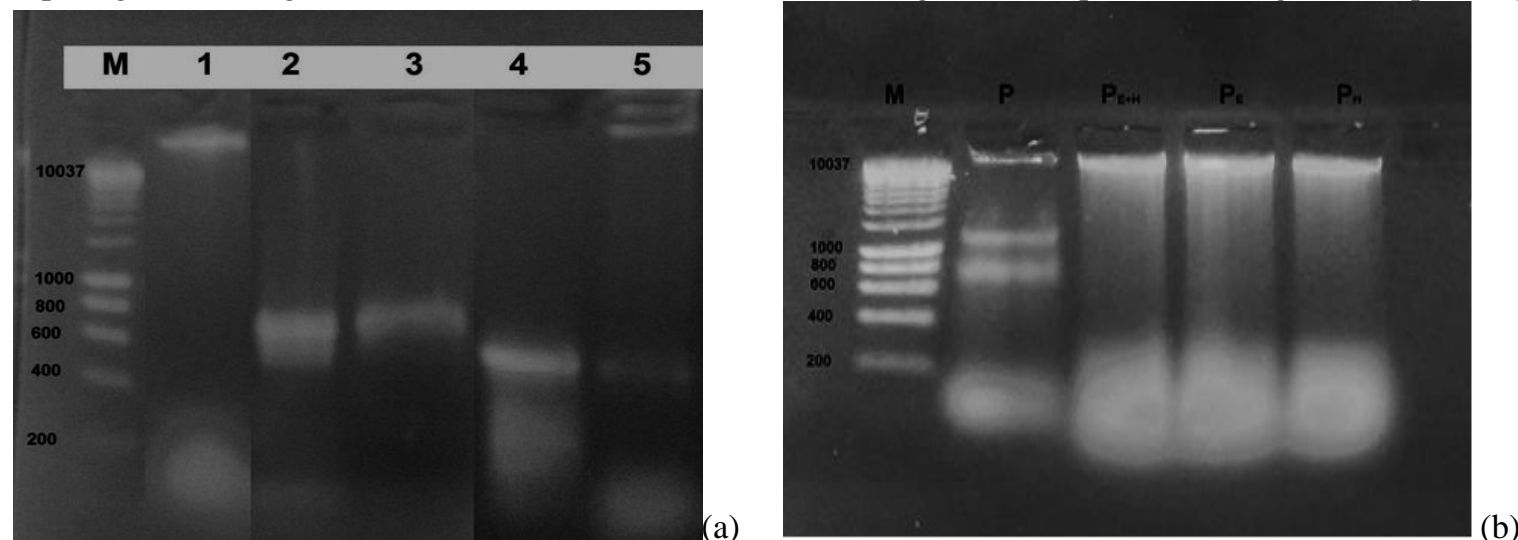

Fig.1 Agarose gel electrophoresis of the restriction digestion. (a) restriction digestion of two thionin genes with their digestion; M: Ladder 1kb, 1: genomic DNA of Arabidopsis thaliana, 2: AT1G12660 gene, 3: digested AT1G12660 gene, 4: AT1G12663 gene and 5: digested AT1G12663 gene. (b)Restriction digestion of vector, lane1 M: molecular weight ladder; lane 2: undigested pEGAD as a control; lane 3: EcoRI/HindIII linearized pEGAD; lane 4: EcoRI linearized pEGAD; lane 5: HindIII linearized pEGAD. 

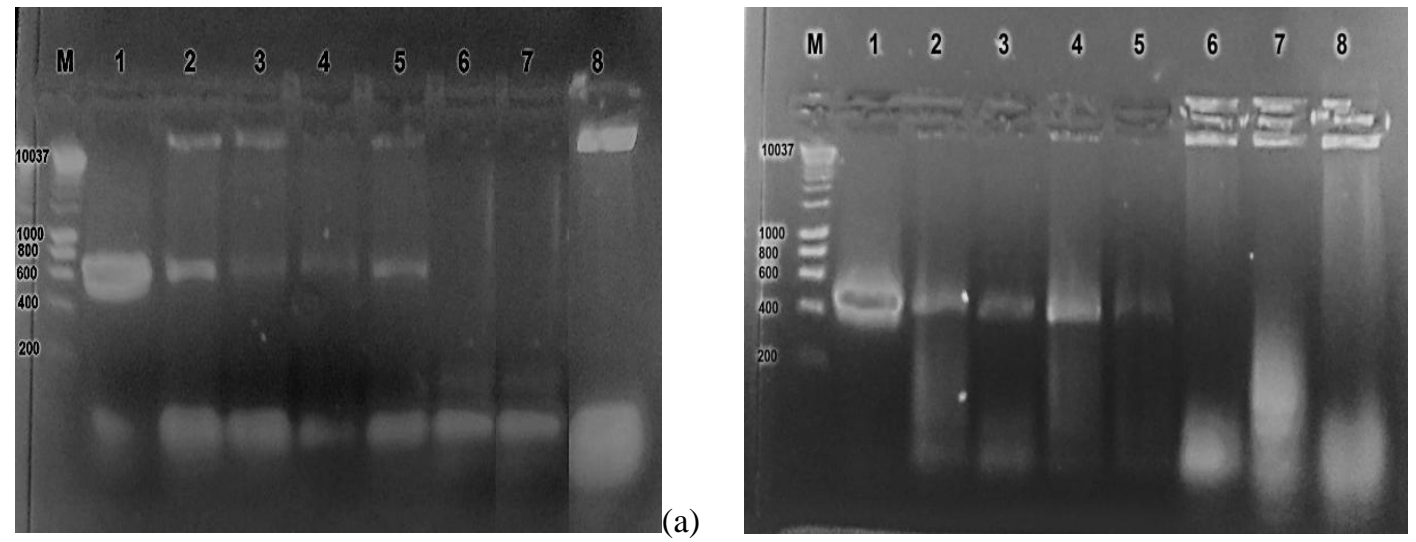

(b)

Fig. (2) Plasmid PCR for confimation of gene insertion into pEGAD vector; (a) for gene 60 and (b) for gene 63 ; where lane 1 is the control gene and lanes (2-8) are the target plasmid with gene for both two genes.

\section{Transformation by Agrobacterium into plant tissue:-}

Figure (3) showed the plates of in vitro regeneration for selection of the transformed segments of Solanumtuberosum with Agrobacterium strain GV3101 for lady cultivar with gene 60; lady cultivar with gene 63; spunta cultivar with gene 60 and spunta cultivar with gene 63 .
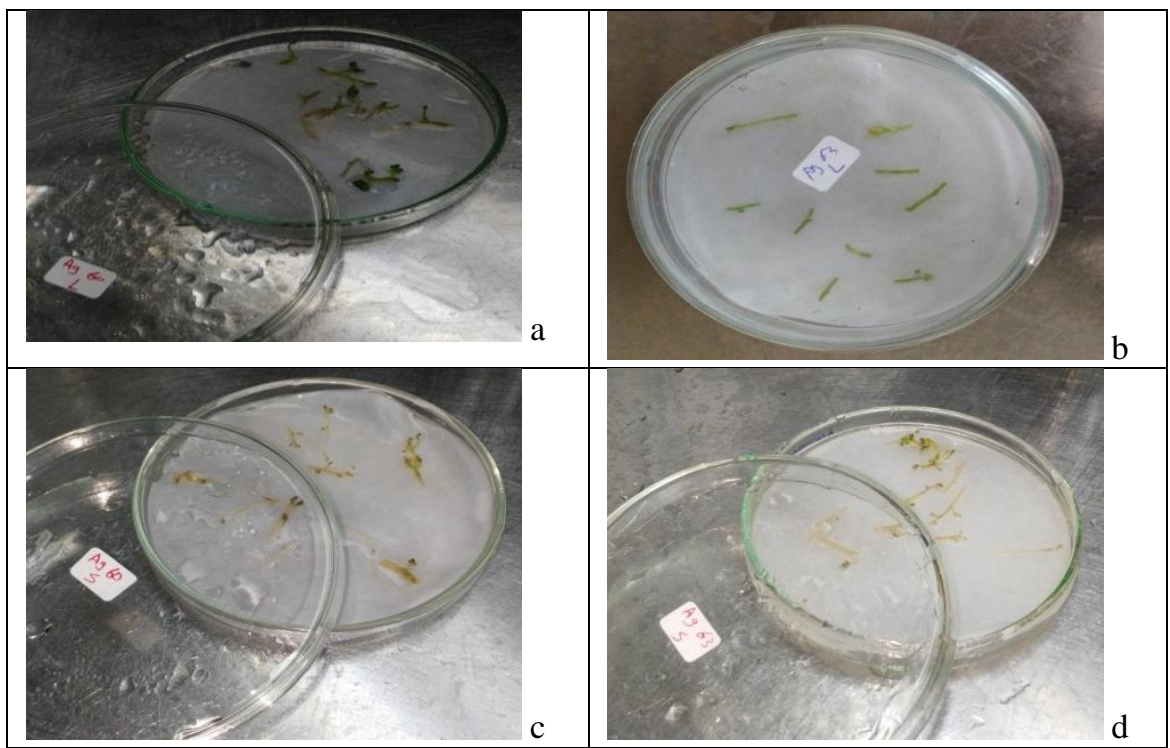

Fig.(3) Plates of in vitro regeneration for selection of the transformed segments of Solanumtuberosum with Agrobacterium strain GV3101 (a) lady cultivar with gene 60; (b) lady cultivar with gene 63; (c) spunta cultivar with gene 60 and (d) spunta cultivar with gene 63 .

The regeneration of the selected transformed segments of both potato cultivars with the two thionin genes on both shooting and rooting MS medium were shown in figure (4).
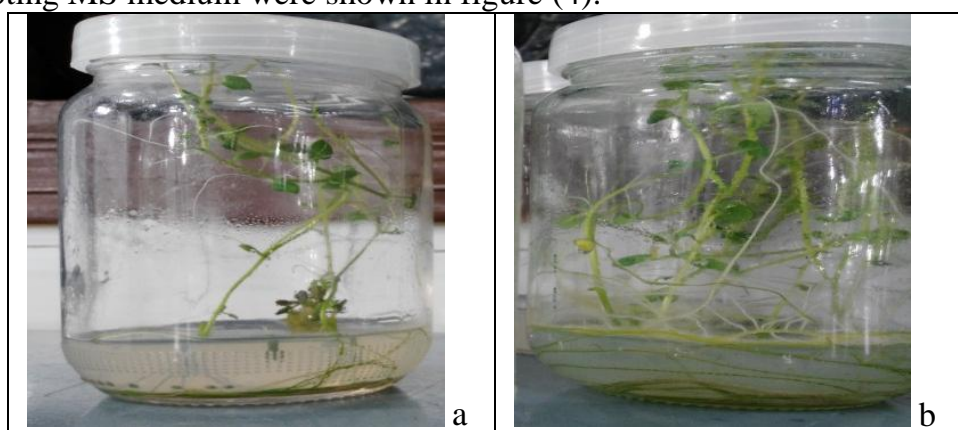


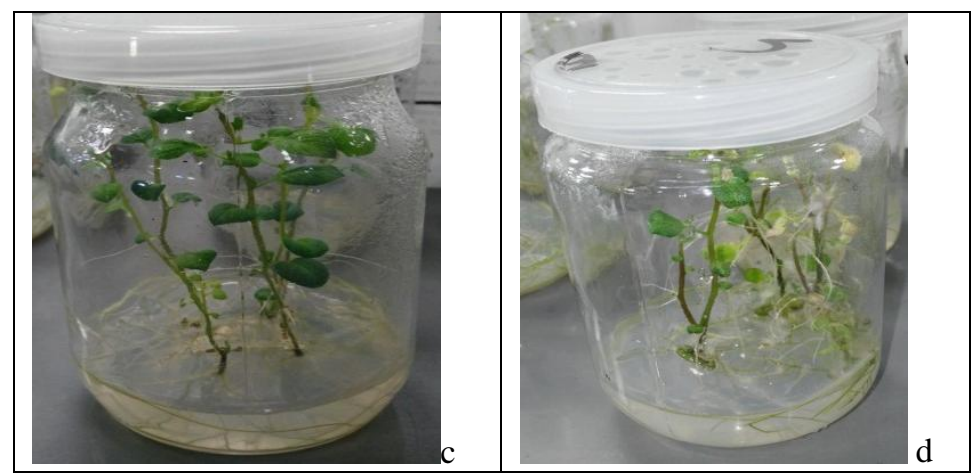

Fig. (4) The selected transformed Solanumtuberosum cultivars on Shooting MS medium via Agrobacterium strain (GV3101) with the two thionin genes: (a) lady cultivar with gene 60; (b) lady cultivar with gene 63; (c) spunta cultivar with gene 60; (d) spunta cultivar with gene 63.

\section{Molecular analysis of the transgenic plant}

4.1. PCR analysis:-The kanamycin-resistant clones were subjected to PCR analysis to confirm the integration of the transgenes Thionin 60 and thionin 63 . Some clones showed amplified fragments of approximately 0.6 $\mathrm{kb}$ for thionin 60 in both lady and spunta cultivars (Fig. 5a,b) and $0.4 \mathrm{~kb}$ for thionin 63 in both lady and spunta cultivars (Fig. 5c,d).No amplified band was shown in PCR products from total DNA of nontransformed control plants.

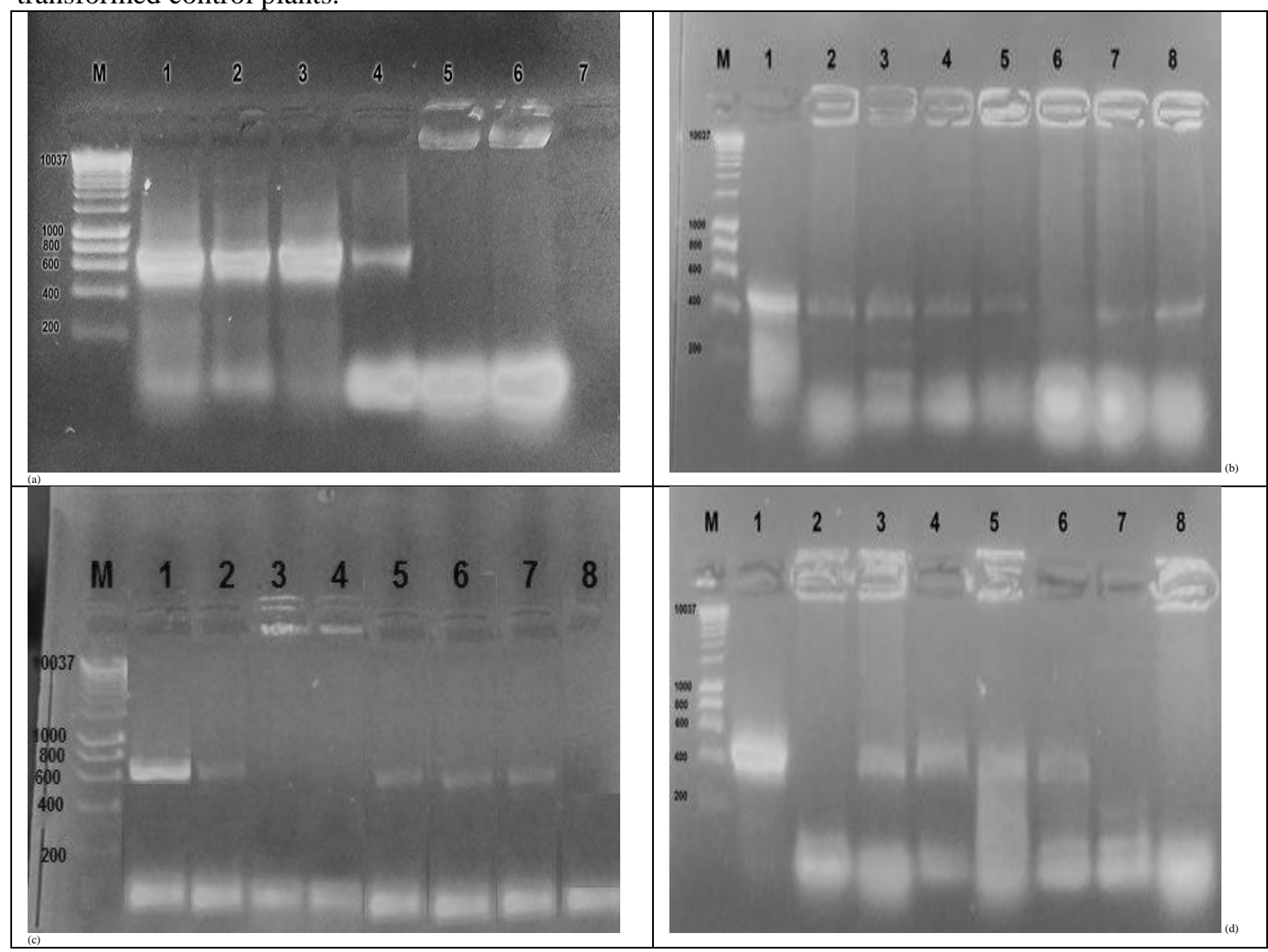

Fig. 5 Polymerase chain reaction (PCR) analysis of potato transformed with thionin 60 and thionin 63 genes.

a)Amplified fragments of thionin 60 gene in lady cultivar $(0.64 \mathrm{~kb})$, b) amplifiedfragment of thionin 60 gene in spunta cultivar $(0.64 \mathrm{~kb}), \mathrm{c})$ amplified fragments of thionin 63 gene in lady cultivar $(0.48 \mathrm{~kb}), \mathrm{d})$ amplified

\subsection{RT-PCR:-}

fragment of thionin 63 gene in spunta cultivar $(0.48 \mathrm{~kb})$.

The reverse transcription of RNAs into cDNAs and theamplification of the specific regions of both Thio60 and Thio63geneswere done to detectthe transcript expression. The result of RT-PCR showed a single $414 \mathrm{bp}$ amplification product for Thio60 gene and a single 348bp amplification product for Thio63 gene. The expression of both thionin genes in transgenic potato is lower than level of transcript expression than actin control gene. Figure (6) showed the expression level of both thionin transcripts in the two potato cultivars in comparing to actin control transcripts. 


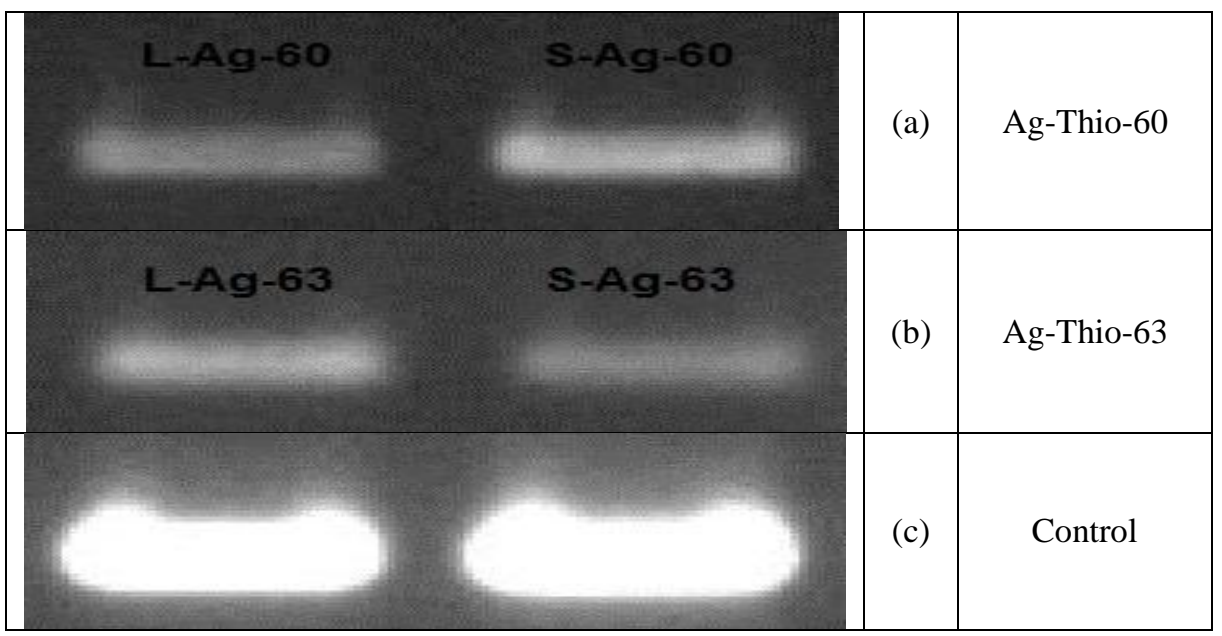

Fig. (6) qRT-PCR for Thionin transcripts in transgenic potato cultivars (lady and spunta); L:lady,S:spunta.

\section{Pathogenicity test:-}

The results of spore suspension of both Fusariumsolani and F. oxysporum on different parts of control and transgenic potato cultivars (detached leaf and micro-tuber) were recorded in table (1). Figure (7) is a histogram explained theinhibitory effect of both $F$. solani and $F$. oxysporum on different organs (detached leaf and micro-tuber) of potato cultivars (control and transgene expressing both thionin genes).In case of detached leaf: $F$. oxysporum causes higher inhibition percentage than $F$. solani in both cultivars in comparing control to transgene. In case of micro-tuber: $F$. solani causes higher inhibition percentage than $F$. oxysporum in both cultivars in comparing control to transgene.The symptoms disease and resistance to infection were recorded in figure (8) and (9) for detached leaf and micro-tuber respectively. The micro-tubers of transgenic potatoes not only partially resist the fungal infection but also able to regenerate shoots again.

Table (1) The average of inhibition percentage for the transgenic potato cultivars measurements in comparing to control against the fungal infection

\begin{tabular}{|c|c|c|c|c|c|}
\hline \multirow[t]{3}{*}{ Fungi } & \multirow[t]{3}{*}{ Transgene } & \multicolumn{4}{|c|}{ Parameter } \\
\hline & & \multicolumn{2}{|c|}{ Detached leaf } & \multicolumn{2}{|c|}{ Micro-tuber } \\
\hline & & Lady & Spunta & Lady & Spunta \\
\hline \multirow[t]{4}{*}{ F. solani } & Control & 38.571 & 37.805 & 52.554 & 54.705 \\
\hline & Ag-60 & 19.874 & 20.085 & 16.344 & 17.112 \\
\hline & Ag-63 & 19.068 & 19.911 & 15.691 & 17.250 \\
\hline & Average Inh.\% & 49.519 & 47.102 & 69.522 & 68.933 \\
\hline \multirow[t]{4}{*}{ F. oxysporum } & Control & 51.876 & 52.758 & 30.508 & 29.926 \\
\hline & Ag-60 & 26.884 & 27.149 & 11.743 & 12.689 \\
\hline & Ag-63 & 27.500 & 26.282 & 12.031 & 12.438 \\
\hline & Average Inh.\% & 47.583 & 49.362 & 61.036 & 58.018 \\
\hline
\end{tabular}

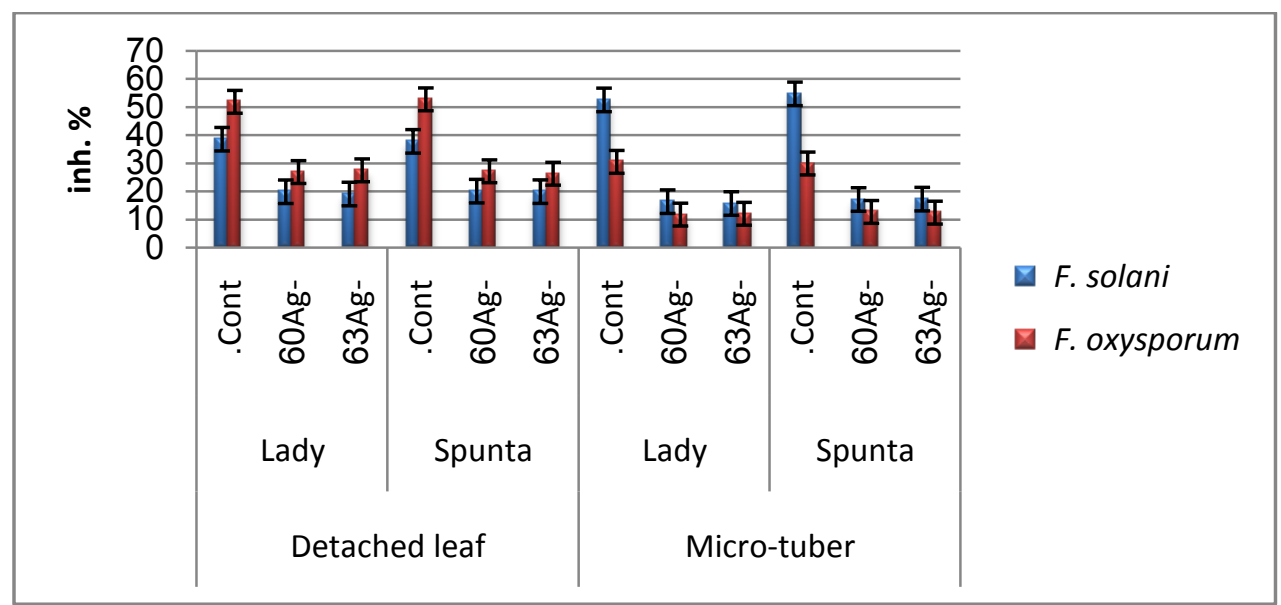

Fig. (7) Histogram showing the inhibition percentage of Fusariumsppaffecting detached leaf and micro-tuber in both lady and spunta cultivars (in case of control and transgene: Ag-60 and Ag-63). 


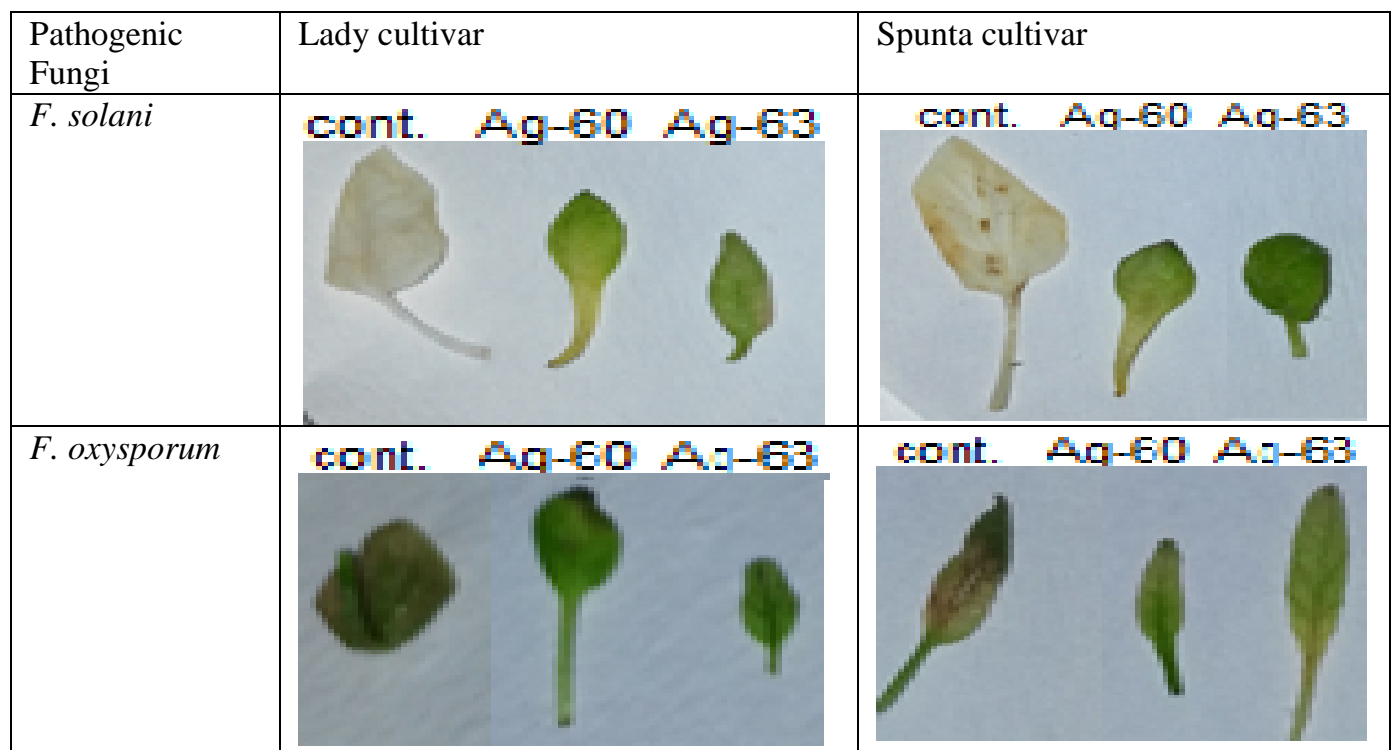

Fig. (8) The effect of spore suspension of different Fusariumspp on detached leaf of potato cultivars. (The arrangement is as follow: control, transgenic with Agor.60 and transgenic with Agro.63).

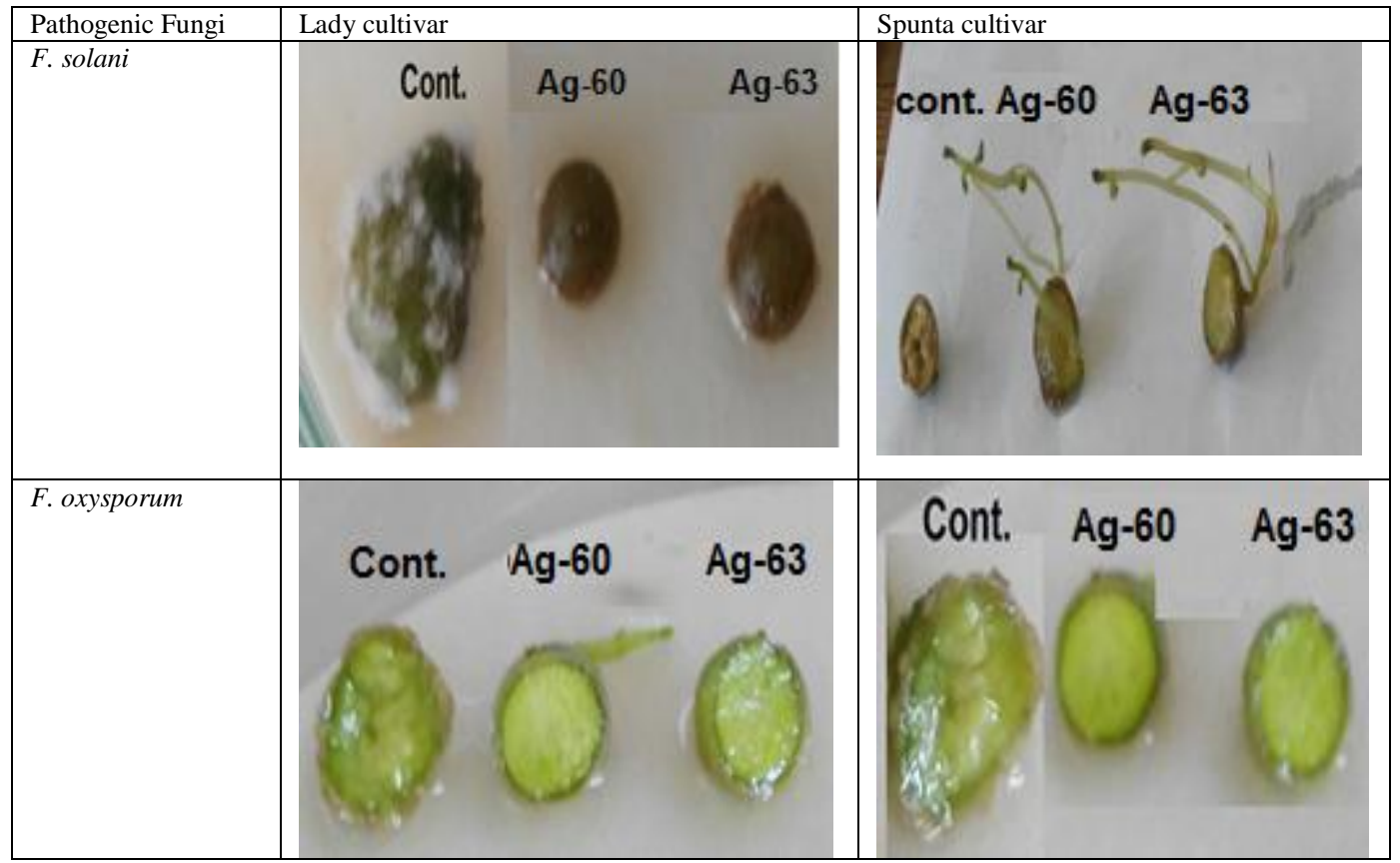

Fig. (9) The effect of spore suspension of different Fusariumspp on micro-tuberof potato cultivars. (The arrangement is as follow: control, transgenic with Agro.60 and transgenic with Agro.63).

\section{Inhibitory effect of protein extracts on spore germination of pathogen Fusariumspp}

The activity of the plant extracts against the spore germination of the different Fusariumspp is represented in Table (2). Figure (10) is a histogram explained the inhibitory effect of crude protein containing both thionins on the germinated spores of both $F$. solani and $F$. oxysporum. It was noticed that out of five protein extracts tested, they have inhibitory effect against the spore germination of these fungi as follow: $52.49 \%$ for thio60 and $47.11 \%$ for thio63 against $F$. solani and $74.47 \%$ for thio60 and $84.08 \%$ for thio63 against F. oxysporum. Figure (11) illustrate the inhibitory effect of protein extract of the transgenic potato cultivars on spore germination of the different four pathogenic fungi.

Table (2) Effect of protein extracts on spore germination of different pathogenic fungi

\begin{tabular}{|l|l|l|l|l|}
\hline \multirow{2}{*}{ Fungi } & Thio60 protein & Thio63 protein \\
\cline { 2 - 5 } & S.G. & Inh. \% & S.G. & Inh. \% \\
\hline F.solani & $40.00 \pm 6.18$ & 52.49 & $21.80 \pm 2.58$ & 47.11 \\
\hline F. oxysporum & $17.40 \pm 1.91$ & 74.47 & $10.60 \pm 1.08$ & 84.08 \\
\hline
\end{tabular}

S.G: Spore germination, Inh \%: Inhibition (\%) 


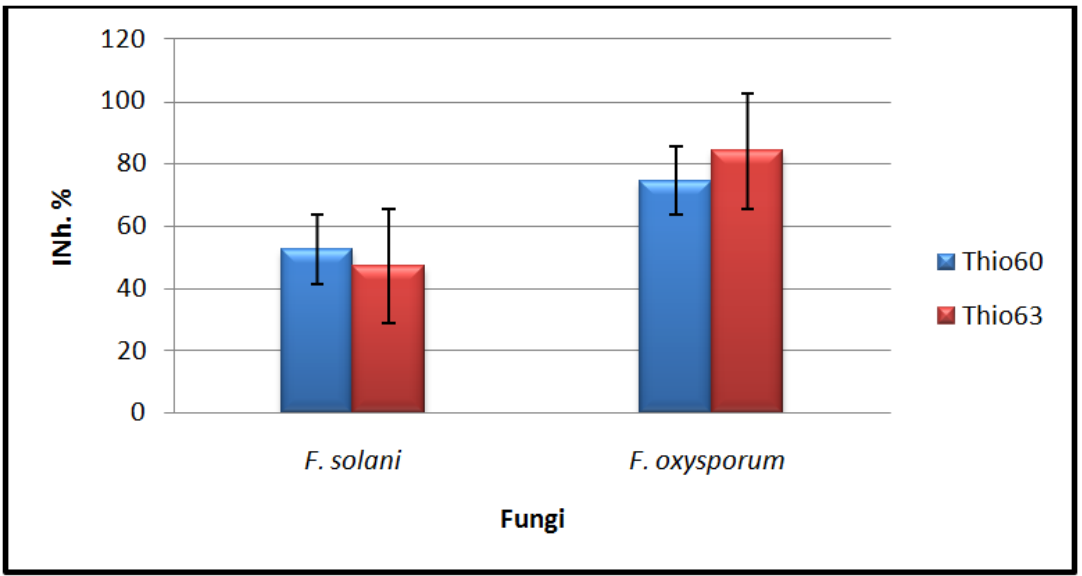

Fig. (10) Histogram showing the inhibition percentage of thionin proteins (Thio60 and Thio63) on spore germination

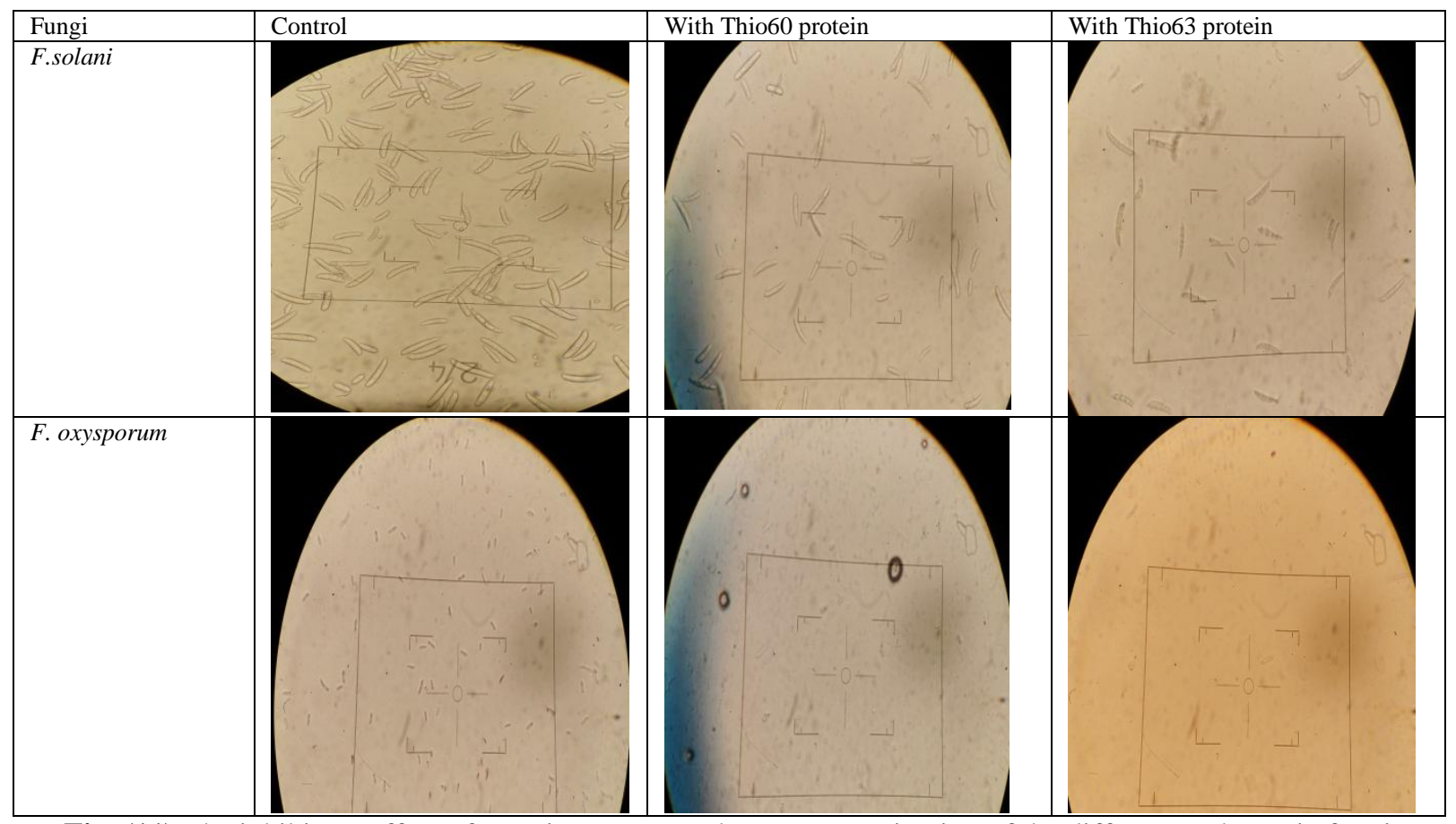

Fig. (11) The inhibitory effect of protein extract on the spore germination of the different pathogenic fungi (magnification power of microscope: 100x)

\section{Discussion}

In this study, the potato cultivars 'lady and spunta' were transformed with an association of Thio60 and Thio63 genes isolated from Arabidopsis thaliana.Potato nodal cutting technique of tissue culture was used for transformation with Agrobacterium tumefaciens. Firstly, tried to infect potato explants with Agrobacterium for different infection times 30,20, 10-minrespectively,with these exposure times our explants did not survive. These results against [23] who worked on three different potato cultivars from France (De'sire'e, Bintje and KaptahVandel)successfully used 30-min infection,[24] from New Jersey, USA who worked on two cultivars (Desiréé and blue potato) and exposed the internodal explants to 20-min infectionand [30] who worked on two different potato cultivars from Bangladesh(LalPakri and Jam Alu)used different infection times $(10,20,30,40$ and 50-min) and all these times succeeded and 50-min was the optimum infection period. So we tried another infection time (5min) 3-days co-cultivation and some explants survive and then transferred for cultivation MS media. This agree with [17] who used 5-min infection into two potato cultivars from Bangladesh (cardinal and heera),[31], from Molecular Plant Pathology Laboratory in USA, who worked on two Serbian potato cultivars (Dragaevka and Jelica) and [32] who worked on different five potato cultivars from Canada (Superior, Bintje, Atlantic, Shepody and Russet Burbank). 
To sum up, the difference in infection periods of explants with Agrobacterium could be due to firstly, used different cultivars which could be differ in their sensitivity to infection with bacteria. Secondly it may be due to use different explants for infection (node, internode or leaf segment), finally it could be due to different environmental conditions which completely different differ from the environmental conditions in Egypt.In this study, we selectednodal explants for transformation because [23] proved that the nodal explants are much more resistant during manipulation and more amenable to in vitro conditions. While[33] mentioned that the leaf explants were easily injured during the manipulation, which resulted in a low percentage of transformation.Thionin genesisolated from Arabidopsis thaliana were expressed in the transgenic potato cultivars and produced thionin proteins which have the ability to inhibit the fungal growth of both pathogenic fungi (Fusariumsolani and $F$. oxysporum). These results agreed with[16] who worked on the secreted antifungal thionin protein isolated from Arabidopsis thaliana and suppressed the toxicity of Fusariumgraminearum, also agreed with [34] who concluded that thionins inhibit the growth in vitro of about 20 different fungal plant pathogens including Botrytiscinerea, Fusarium spp., Phytophthorainfestans and Rhizoctoniasolani,[35] also observed that constitutive overexpression of an endogenous thionin in transgenic Arabidopsis resulted in enhanced resistance against Fusarium oxysporum f. sp. matthiolae, which indicates that thionins are defense proteins and[36] were also agreed with our work, who approved that the effective concentration of Thionins of type I, from the endosperms of wheat (Wal, Wa2, W $\beta$ ) and barley $(\mathrm{B} \alpha, \mathrm{B} \beta)$, and of type II, from barley leaves (BLa, BLb, BLc),giving about 50\% inhibition for strains of some bacterial species, such as Clavibactermichiganensis subsp. sepedonicus or Pseudomonas solanacearum; and some fungal pathogens, such as Rosellinianecatrix, ColletotrichumlagenariumandFusariumsolani. [16]Proved that wheat thionin also accumulates in the cell walls of Fusarium-inoculated plants, suggesting that it may have a role in blocking pathogen infection at the plant cell walls.

\section{Acknowlegment}

The corresponding author gratefully acknowledge Mr. Mohammed Fathy (Tissue culture laboratory, Agricultural center for genetic engineering and biotechnology "ACGEB", Faculty of Agriculture, Ain Shams University) for his effort in this work in the part of tissue culture of plants.

[1] J.E. Edmonds, M.S. Vorontsova, and S. Knapp, Solanaceae, In: Flora of Tropical East Africa, ed. H. Beentje, Royal Botanic Gardens, Kew, 2012

[2] S.S. Kabeil, S.M. Lashin, M.H. El- Masry, M.A. El-Saadani, M.M. Abd-Elgawad, and A.M. Aboul-Einean,: Potato Brown Rot Disease in Egypt: Current Status and Prospects, American-Eurasian J. Agric. and Environ. Sci., 4 (1), 2008, 44-54.

[3] S.I.A Elawady and A.Y. Abdulkheir, An Economic Study of the Growth Determinants for the Egyptian Potatoes Exports to the Global Market, International Journal of Economics and Finance, 7(7), 2015, 89-97.

[4] H.A.M. Mahgoub, G.S.A. Eisa and M.A.H. Youssef, Molecular, biochemical and anatomical analysis of some potato (Solanumtuberosum L.) cultivars growing in Egypt, Journal of Genetic Engineering and Biotechnology, Elseveir. 13, 2015, 39-49.

[5] M.A. Draper, G.A. Secor and H.A. Lamey, Managements of potato diseases in the home garden. NDSU; 1994, 1-8.

[6] L. Tamm, B. Smit, M. Hospers, B. Janssens, J. Buurma, J.P. Mølgaard, P.E. Lærke, H.H. Hansen, L. Bodker, C. Bertrand, J. Lambion, M.R. Finckh, C. Schüler, E. Lammerts van Bueren, T. Ruissen, S. Solberg, B. Speiser, M. Wolfe, S. Phillips, S.J. Wilcockson and C. Leifert, Assessment of the socio-economic impact of late blight and state-of-theart management in European organic potato production systems, (published by FiBL; Frick, Switzerland), Chapter two, 2004, 15-119.

[7] H. Zhang, G. Li, W. Li and F. Song, Transgenic strategies for improving rice disease resistance, African Journal of Biotechnology 8 (9), 2009, 1750-1757.

[8] A.S. Walker, A. Micoud, F. Rémuson, J. Grosman, M. Gredt and P. Leroux, French vineyards provide information that opens ways for effective resistance management of Botrytis cinerea (greymould), PestManagSci 69, 2013, 667-678.

[9] H. Van der Heyden, P. Dutilleul, L. Brodeur and O. Carisse, Spatial distribution of single nucleotide polymorphisms related to fungicide resistance and inference for sampling, 2014.

[10] V.Erukhimovitch, L. TsrorLahkim, M. Hazanovsky, M. Talyshinsky, Y. Souprun, M. Huleihel,Early and rapid detection of potato's fungal infection by Fourier transform infrared microscopy. ApplSpectrosc. 61(10), 2007, 1052-1056.

[11] P. Wharton, W. Kirk, D. Berry, and S. Snapp, Michigan potato diseases, Rhizoctonia stem canker and blackscurf of potato, Michigan extension bulletin. 2007.

[12] M. Aktaruzzaman, S. Xu, J. Kim, J. Woo, Y. Hahm, B. Kim, First Report of Potato Stem-End Rot Caused by Fusariumoxysporum in Korea. Mycobiology. 42(2), 2014, 206-209.

[13] K. Hoshikawa, G. Ishihara, H. Takahashi and I. Nakamura, Enhanced resistance to gray mold (Botrytis cinerea) in transgenic potato plants expressing thionin genes isolated from Brassicaceae species, Plant Biotechnology 29, 2012, 87-93.

[14] Z. Sadati, M.A. Tajik Ghanbari, V. Babaeizad, and H. Rahimian, Expression of thionin and PDF1.2 coding genes as antimicrobial peptides in interaction of rice against rice blast agent, Magnaportheoryzea, Iran. J. Plant Path., 50 (4), 2014, 147-149.

[15] K.Y. Kurtoglu, E. Filiz, I.I. Ozyigit and R. Vatansever, Genome-Wide Analysis of Thionin Genes in Higher Plants, Plant and animal genome conference XXIII. San Diego, CA. 2015.https://pag.confex.com/pag/xxiii/webprogram/Paper14677.html

[16] T. Asano, A. Miwa, K. Maeda, M. Kimura, and T. Nishiuchi, The Secreted Antifungal Protein Thionin 2.4 in Arabidopsis thaliana Suppresses the Toxicity of a Fungal Fruit Body Lectin from Fusariumgraminearum, PLoSPathog 9(8): 2013, e1003581.

[17] A. Khatun, M.M. Hasan, M.A.A. Bachchu, M. Moniruzzaman, K.M. Nasiruddin, Agrobacterium-mediated Genetic Transformation of Potato (Solanumtuberosum L.) var. Cardinal and Heera. The Agriculturists. 10 (1), 2012, 81-86.

[18] T. Murashige and K. Skoog, A revised medium for rapid growth and bioassays with tobacco tissue cultures,Physiol. Plant, 15, 1962, 473-497. 
[19] Y. Lu, S. Chanroj, L. Zulkifli, M.A. Johnson, N. Uozumi, A. Cheung and H. Sze, Pollen tubes lacking a pair of K+ transporters fail to target ovules in Arabidopsis. Plant Cell 23(1), 2011, 81-93.

[20] T. Maniatis, E.F. Fritsch, J. Sambrook, Molecular cloning: A laboratory manual. (2nd ed.). Cold spring harbor laboratory, New York, U.S.A. 1989.

[21] M. Kavas, Development of salt resistant transgenic plants by using TANHX1 and TASTR genes. The degree of doctor of philosophy in biology, the graduate school of natural and applied sciences of middle east technical university, 2011.

[22] M. Holsters, D. De Waele, A. Depicker, E. Messens, M. van Montagu, J. Schell,Transfection and transformation of Agrobacterium tumefaciens. Mol Gen Genet. 163, 1978, 181-187.

[23] A. Beaujean, R.S. Sangwan, A. Lecardonnel and B.S. Sangwan-Norreel, Agrobacterium-mediated transformation of three economically important potato cultivars using sliced internodal explants: an efficient protocol of transformation, Journal of Experimental Botany, 49( 326), 1998, 1589-1595.

[24] M.L. Orozco-Cárdenas, V.J. Chetty, J. Narváez-Vásquez, Potato (Solanumtuberosum L.) Methods in Molecular biology, Agrobacterium Protocols edited by Kan Wang. Third Edition Volume 2, Humana Press. Totowa, New Jersey. In press. 2014.

[25] S. Yadav, P. Sharma, A. Srivastava, P. Desai and N. Shrivastava, Strain specific Agrobacterium-mediated genetic transformation of Bacopamonnieri, Journal of Genetic Engineering and Biotechnology 12, 2014, 89-94.

[26] D.Bartels, K. Schneider, G. Terstappen, D. Piatkowski, F. Salamini,Molecular cloning of abscisic acid-modulated genes which are induced during desiccation of the resurrection plant Craterostigmaplantagineum. Planta. 181, 1990, 27-34.

[27] R.S. Khan, R. Sjahril, I. Nakamura, M. Mii, Production of transgenic potato exhibiting enhanced resistance to fungal infections and herbicide applications, Plant Biotechnol Rep 2, 2008, 13-20.

[28] M.M. Bradford, A Rapid and Sensitive Method for the Quantitation of Microgram Quantities of Protein Utilizing the Principle of Protein-Dye Binding, Anal., Biochem. 72, 1976, 248-254.

[29] M.D. Maji, S. Chattopadhyay, P. Kumar, B. Saratchandra, In vitro screening of some plant extracts against fungal pathogens of mulberry (Morus spp.). Arch. Phytopathol. Plant Prot. 38, 2005, 157-164.

[30] R.H. Sarker, B.M. Mustafa, Regeneration and Agrobacterium-mediated Genetic Transformation of Two Indigenous Potato Varieties of Bangladesh.Plant Tissue Cult. 12(1), 2002, 69-77.

[31] A. Cingel, B. Vinterhalter, D. Vinterhalter, D. Cali-Dragosavac, A. Smigocki and S. Ninkovi, Agrobacterium-mediated transformation of two Serbian potato cultivars (Solanumtuberosum L. cv. Dragaevka and cv. Jelica), African Journal of Biotechnology, 9(30), 2010,4644-4650.

[32] B. Chakravarty and G. Wang-Pruski, Rapid regeneration of stable transformants in cultures of potato by improving factors influencing Agrobacterium-mediated transformation, Advances in Bioscience and Biotechnology, 1, 2010, 409-416.

[33] M. De Block, Genotype-independent leaf disc transformation of potato (Solanumtuberosum) using Agrobacterium tumefaciens, Theoretical and Applied Genetics 76, 1988, 767-74.

[34] B.P.A.Cammue, M.F.C. De Bolle, F.R.G. Terras, P. Proost, J. Van Damme, S.B. Rees, J. Vanderleyden, W.F. Broekaert, Isolation and characterization of a novel class of plant antimicrobial peptides from Mirabilis jalapa L. seeds. Journal of Biological Chemistry 267, 1992, 2228-2233.

[35] P. Epple, K. Apel, H. Bohlmann, Overexpression of an endogenous thionin enhances resistance of Arabidopsis against Fusariumoxysporum. Plant Cell. 9, 1997, 509-520.

[36] A. Molina, P. Ahl Goy, A. Fraile, R. Sánchez-Monge, F. García-Olmedo, Inhibition of bacterial and fungal pathogens by thionins of types I and II. Plant Science 92, 1993, 169-177.

I.A. Hammad. "Transgenic Potato (Solanumtuberosum) Expressing Two Antifungal Thionin Genes Confer Resistance To Fusarium Spp." IOSR Journal of Pharmacy and Biological Sciences (IOSR-JPBS) 12.4 (2017): 69-79. 